\title{
FINE-ROOT VERTICAL PROFILE，PRODUCTION, MORTALITY AND DECOMPOSITION IN AN ACACIA PLANTATION IN NORTH-EAST VIETNAM
}

\author{
Tran Van Do \\ Silviculture Research Institute, Vietnamese Academy of Forest Sciences, Hanoi, Vietnam; dotranvan@hotmail.com
}

Submitted August 2019; accepted January 2020

\begin{abstract}
Fine-roots drive plant growth and influence the global carbon cycle. Thus understanding their production and distribution is useful for plantation management. Therefore, in the present study, the vertical distribution and production of fine-roots were investigated in a 2-year-old Acacia plantation in Vietnam that had a planting density of 1100 trees $\mathrm{ha}^{-1}$. A $30 \mathrm{~m} \times 30 \mathrm{~m}$ plot was established in the plantation and field data were collected using sequential soil core sampling and the litter bag technique. The continuous inflow method was used to estimate fine-root production, mortality and decomposition during spring, summer, fall and winter. More than $78.0 \%$ of the fine-roots were distributed in the $0-20 \mathrm{~cm}$ soil layer while less than $4.0 \%$ were distributed in the $50-80 \mathrm{~cm}$ later. The proportion of fine-roots in the $0-20 \mathrm{~cm}$ layer was greater in summer $(81.0 \%$ ) than in winter $(78.0 \%$ ), while the reverse was true in the $50-80 \mathrm{~cm}$ layer (summer $2.3 \%$, winter $3.6 \%$ ). The total fine-root production, mortality and decomposition in the study area were $9.90,8.39$ and 7.07 tonnes $\mathrm{ha}^{-1}$ year-1 respectively and all three of these parameters were seasonally dependent, being higher in summer $\left(>2.5 \mathrm{~g} \mathrm{~m}^{-2}\right.$ day $\left.^{-1}\right)$ than in winter $\left(<1.5 \mathrm{~g} \mathrm{~m}^{-2} \mathrm{day}^{-1}\right)$.
\end{abstract}

Keywords: Decomposition, fine-root, seasonal-dependent, soil carbon, vertical distribution

\section{INTRODUCTION}

Tropical rainforests have high levels of gross and net primary production and high biomasses (Luyssaert et al. 2007) and consequently make significant contribution to carbon cycling at a global scale. Roots with a diameter of $\leq 2 \mathrm{~mm}$ are known as fine-roots (Osawa \& Aizawa 2012) and play an important role in plant growth and the global carbon cycle (Saifuddin \& Normaniza 2016). Indeed, the annual addition of carbon to the soil through fine-root mortality can equal or even exceed that of leaf litter (Freschet et al. 2013), and fine-root production has been estimated to account for $10-60 \%$ total net primary production in tropical forests (Gill \& Jackson 2000, Malhi 2012). Fine-roots capture and transport water and nutrients that are required by plants (McCormack \& Guo 2014) but only survive for several weeks or months, which is much shorter than the lifespan of trees. Fine-roots are considered an important source and sink of nutrients in terrestrial biogeochemistry (Gordon \& Jackson 2000). The production of fine-roots varies with vegetation type, edaphic and climate conditions, and geographical location (Inagaki et al. 2009) Even at the same site, fine-root production and dynamics vary between seasons, nutrient levels and soil depths (Lai \& Tran 2019, Nguyen et al. 2019) .

Previous studies of vertical distribution of fine-roots found that $80 \%$ of fine-roots occur in the $0-20 \mathrm{~cm}$ soil layer in both plantation and natural forests (Tran \& Sato 2018, Lai \& Tran 2019), indicating that fewer fine-roots are distributed in deeper soil depths. Fine-roots are important for reducing nutrient losses through leaching and improving the drought tolerance of trees by allowing water to be absorbed from deeper soil when the surface layers are dry (Laclau et al. 2010). Fine-root decomposition also returns more carbon and nutrients to the soil than aboveground decomposition, making this a significant pathway for nutrient and carbon cycling in forests (Tran \& Sato 2018, Katayama et al. 2019).

Plantations of fast-growing trees have rapidly expanded globally in the last 30 years, increasing from approximately $168 \mathrm{mil}$ ha in 1990 to 278 mil ha in 2015 (Keenan 2015). In SouthEast Asia, Acacia species in particular have been widely planted, and these plantations now cover approximately $1 \mathrm{mil}$ ha in Vietnam (Kien et al. 
2014), and they make a considerable contribution to the country's economy and reduce poverty in remote regions where logging of timber from natural forests is prohibited. However, while numerous studies have investigated fine-roots in a range of forest ecosystems (Valverde-Barrantes et al. 2007, Yan et al 2019), relatively few have considered their characteristics in Acacia plantations (Inagaki et al. 2009), despite the importance of such information for sustainable plantation management. Therefore, the aim of the present study was to investigate the vertical distribution of fine-roots and to estimate their production, mortality and decomposition in an Acacia hybrid plantation in north-east Vietnam.

\section{MATERIALS AND METHODS}

\section{Description of the study site}

This research was conducted at the Forest Experiment Station of the College of Agriculture and Forestry, north-east Vietnam $\left(21^{\circ} 4^{\prime} \mathrm{N}, 106^{\circ}\right.$ $48^{\prime} \mathrm{E}$ ). This area has a mean annual temperature of $22.2{ }^{\circ} \mathrm{C}$ and air humidity of $81 \%$ (QCVN02 2009) and is influenced by the monsoon climate with four distinct seasons: spring (FebruaryApril), summer/rainy season (May-August), fall (September-November), and winter/dry season (December-February). Details of the air and soil temperatures in 2018-are shown in Figure 1(a). Annual precipitation is $1600-2200$ $\mathrm{mm}$ over 153 rainy days, $1159 \mathrm{~mm}$ of which falls in the rainy season (Figure 1b).

The site is located on flat land that was classified as bare land with some short shrubs and bushes prior to Acacia being grown. All of the vegetation was cleared and burned to prepare the site for planting Acacia. The soil at the site is classified as Ferralic Acrisol and is $70-80 \mathrm{~cm}$ deep. The soil has a $\mathrm{pH}$ of 3.7 and an organic matter content of $2.7 \%$, nitrogen content of $0.18 \%$, phosphorus content of 2.3 $\mathrm{mg} \mathrm{P}_{2} \mathrm{O}_{5} 100 \mathrm{~g}^{-1}$ soil, potassium content of 3.4 $\mathrm{mg} \mathrm{K}_{2} \mathrm{O} 100 \mathrm{~g}^{-1}$ soil and a soil bulk density of $1.21 \mathrm{~g} \mathrm{~cm}^{-3}$. The soil comprises $58.3 \%$ sand, $21.9 \%$ loam and $19.8 \%$ silt (Nguyen et al. 2019).

The experiments were conducted in a 2-yearold Acacia hybrid plantation that had been planted using in vitro seedlings having super genotype at a density of 1100 trees ha $^{-1}$ (spacing $3 \mathrm{~m} \times 3 \mathrm{~m}$ ). Trees in the plantation had a mean stem height of $9.8 \mathrm{~m}$ and a mean stem diameter at breast height of $9.9 \mathrm{~cm}$. All stem crowns overlapped so that there was no open sky, and there were no dead trees in the study area.
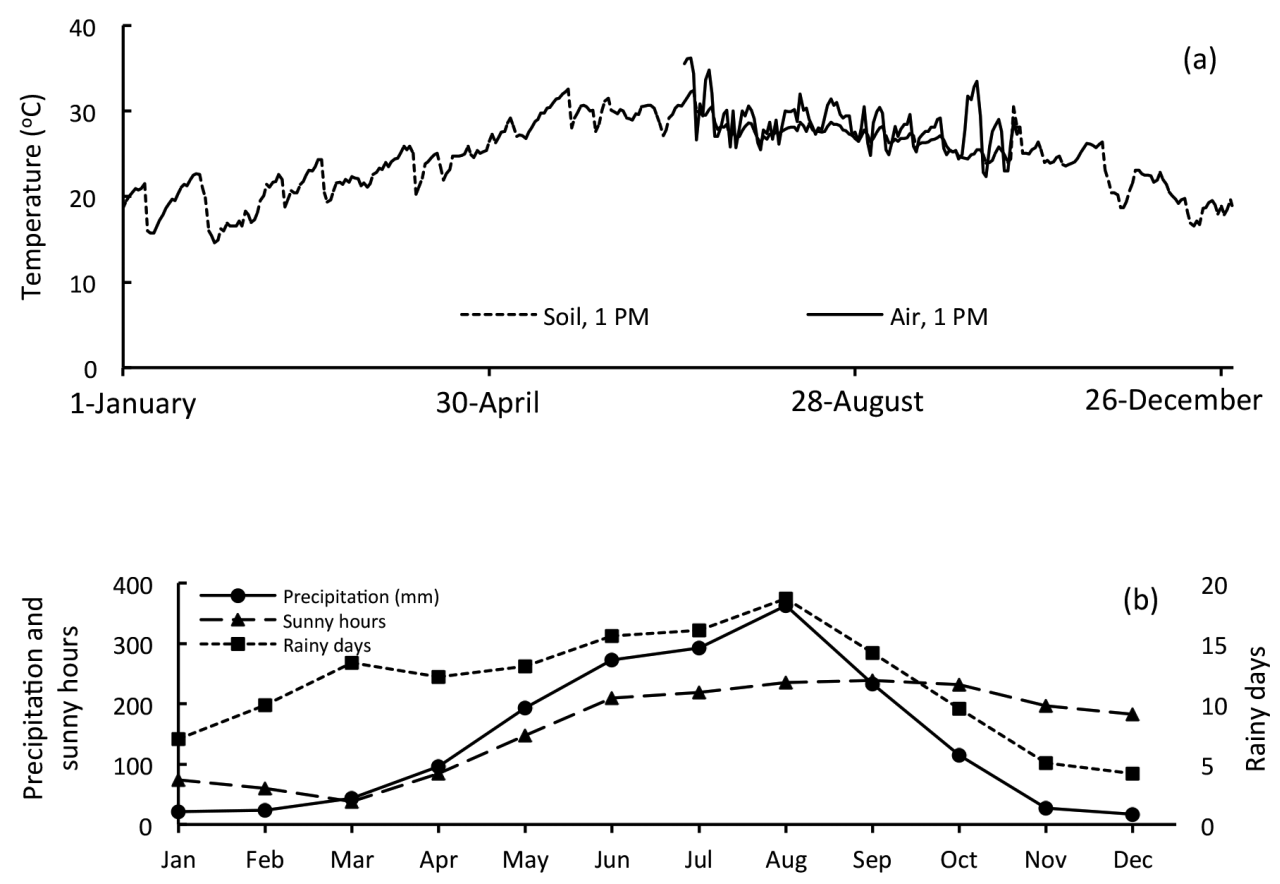

Figure 1 Changes of daily temperature in 2018 (a) and average of 10-year records of precipitation, sunny hours and rainy days (b); early rainy season starts late May/early June when precipitation is higher than $100 \mathrm{~mm} \mathrm{month}^{-1}$ 


\section{Plot establishment and data collection}

A $30 \mathrm{~m} \times 30 \mathrm{~m}$ plot was established in the Acacia plantation. Data were collected from the plot comprising 81 trees $\left(9\right.$ lines $\times 9$ trees line $^{-1}$ ) using sequential soil core sampling and the litter bag technique. A steel tube with an inner diameter of $34 \mathrm{~mm}$ was used to obtain soil cores to a depth of $20 \mathrm{~cm}$ in December 2017 and March, June, September and December 2018. On each sampling date, 45 cores were randomly collected from the plot. The collected soil was washed with tap water and sieved to obtain clean fineroots (Osawa \& Aizawa 2012). These were then air dried for several days, following which they were classified as dead or live roots based on their colour: dark/black for dead fine-roots and bright/yellow for live fine-roots. The separated dead and live fine-roots were oven dried at $80^{\circ} \mathrm{C}$ until they reached a constant mass, which was measured separately for live roots (biomass) and dead roots (necromass).

To measure the decomposition ratio of dead fine-roots in the field, litter bags of $10 \mathrm{~cm} \times 10 \mathrm{~cm}$ (Osawa \& Aizawa 2012) were made using cloth with pore size of $0.6 \mu \mathrm{m}$, which prevented fineroots from growing through the bags while allowing fine soil, water and microorganisms to penetrate for fine-root decomposition. Approximately $0.4-0.6 \mathrm{~g}$ of dry necromass and 7-10 $\mathrm{g}$ of fine soil were placed in each litter bag. In December 2017, 18 litter bags were buried at a soil depth of $10-15 \mathrm{~cm}$ at random locations in the study plot. The buried bags were collected in March 2018 and 18 new litter bags were buried at random locations. This procedure was then repeated at the start of each interval, i.e. June, September and December 2018. Following collection, the remaining roots inside the litter bags were collected by washing and sieving and were oven dried to constant mass. Decomposition ratio $(\gamma)$ was then estimated as $\gamma=[$ (initial mass - remaining mass)/initial mass] for each of the four time intervals.

\section{Data analysis}

Fine-root production (P) (equation 1), mortality (M) (equation 2) and decomposition (D) (equation 3) were estimated using the continuous inflow method (Osawa \& Aizawa 2012):

$$
\begin{aligned}
\mathrm{P}= & \left(\mathrm{B}_{\mathrm{j}}-\mathrm{B}_{\mathrm{i}}\right)+\left(\mathrm{N}_{\mathrm{j}}-\mathrm{N}_{\mathrm{i}}\right)+\left[-\left(\mathrm{N}_{\mathrm{j}}-\mathrm{N}_{\mathrm{i}}\right)\right. \\
& \left.-\left(\left(\mathrm{N}_{\mathrm{j}}-\mathrm{N}_{\mathrm{i}}\right) / \gamma_{\mathrm{ij}}+\mathrm{N}_{\mathrm{i}}\right) * \ln \left(1-\gamma_{\mathrm{ij}}\right)\right]
\end{aligned}
$$

$$
\begin{aligned}
\mathrm{M}= & \left(\mathrm{N}_{\mathrm{j}}-\mathrm{N}_{\mathrm{i}}\right)+\mathrm{D} \\
\mathrm{D}= & -\left(\mathrm{N}_{\mathrm{j}}-\mathrm{N}_{\mathrm{i}}\right)-\left(\left(\mathrm{N}_{\mathrm{j}}-\mathrm{N}_{\mathrm{i}}\right) / \gamma_{\mathrm{ij}}+\mathrm{N}_{\mathrm{i}}\right) \\
& * \ln \left(1-\gamma_{\mathrm{ij}}\right)
\end{aligned}
$$

where, $B_{i}$ and $B_{j}$ are the biomasses of live fineroots at times $t_{i}$ and $t_{j}$ respectively (where $t_{j} \geq t_{i}$ ), $\mathrm{N}_{\mathrm{i}}$ and $\mathrm{N}_{\mathrm{j}}$ are the necromasses of dead fineroots at times $t_{i}$ and $t_{j}$ respectively, and $\gamma_{i j}$ is the decomposition ratio of dead fine-roots for the corresponding time interval. $\mathrm{B}_{\mathrm{i}}, \mathrm{B}_{\mathrm{j}}, \mathrm{N}_{\mathrm{i}}$, and $\mathrm{N}_{\mathrm{j}}$ were obtained by soil core sampling, and $\gamma_{\mathrm{ij}}$ was obtained using the litter bag technique as outlined above.

Fine-root production, mortality and decomposition during the four time intervals were estimated using the bootstrap method (Osawa \& Aizawa 2012). Mean 95\% confidence limit was calculated using bias-corrected percentile approach, whereby the dataset was randomly sampled 45 times to obtain the mean and this was repeated 1000 times (Efron \& Gong 1983).

The differences in fine-root biomass and necromass between the five collection times, and the differences in the fine-root decomposition ratio, production, mortality and decomposition between the four collection intervals were evaluated using univariate analysis of variance (ANOVA) and post hoc tests at $p=0.05$. All analyses were conducted using SAS 9.2.

\section{RESULTS}

\section{Vertical distribution of live fine-roots}

More than $78 \%$ of fine-roots were distributed in the $0-20 \mathrm{~cm}$ soil layer, while less than $4 \%$ were distributed in the $50-80 \mathrm{~cm}$ layer (Figure 2). The proportion of fine-roots in the $0-20 \mathrm{~cm}$ soil layer was higher in summer $(81 \%)$ than in winter $(78 \%)$, whereas the proportion in the $50-80 \mathrm{~cm}$ soil layer was higher in winter $(3.6 \%)$ than in summer $(2.3 \%)$.

\section{Decomposition ratio of dead fine-roots}

The decomposition ratio of dead fine-roots significantly differed between collection intervals (Figure 3). The highest decomposition ratio was observed in December-March $\left(0.00908\right.$ day $\left.^{-1}\right)$, followed by March-June $\left(0.00810\right.$ day $\left.^{-1}\right)$, JuneSeptember $\left(0.00712 \mathrm{day}^{-1}\right)$, and SeptemberDecember $\left(0.00666\right.$ day $\left.^{-1}\right)$. 

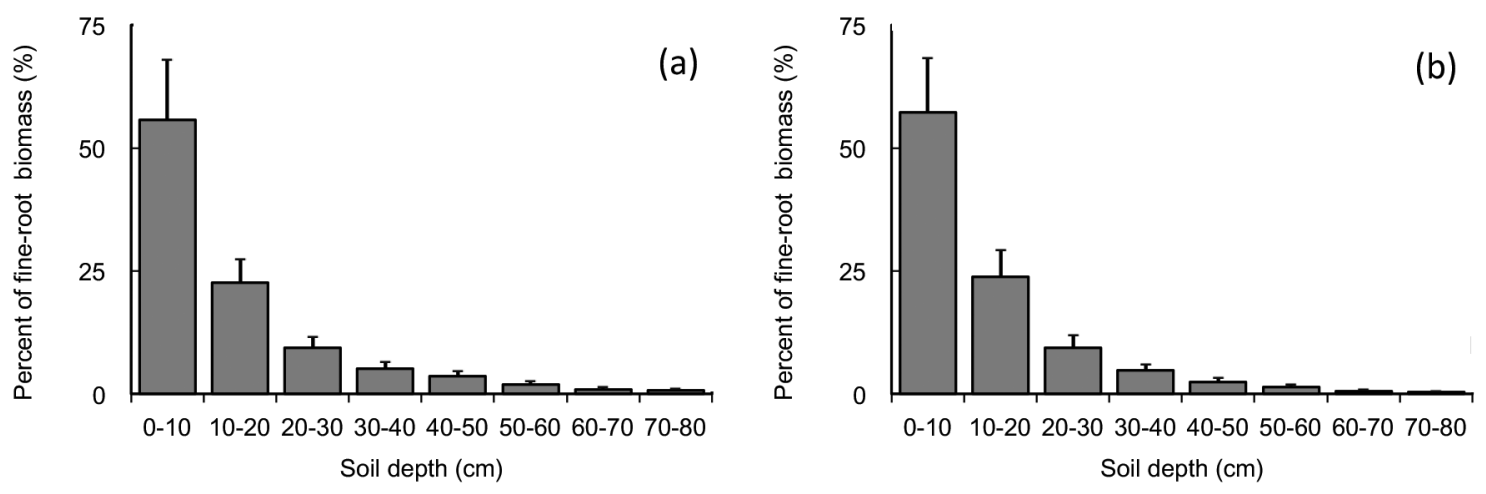

Figure 2 Vertical distribution of fine-roots-in December/dry season 2017 (a) and June/rainy season 2018 (b); bars indicate \pm standard errors

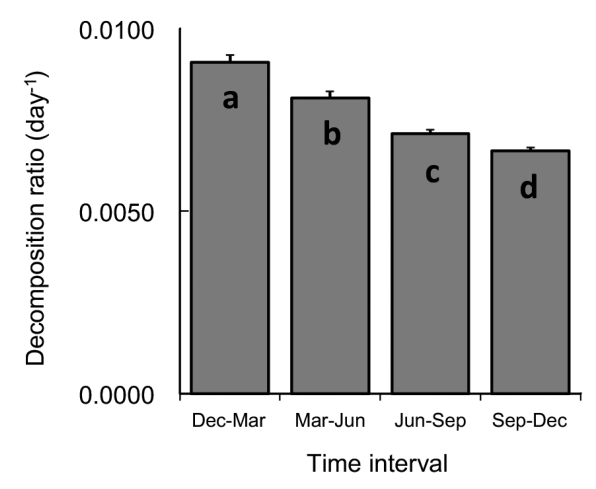

Figure 3 Decomposition ratio of dead fine-roots in different time durations; bars indicate \pm standard errors, different letters indicate significant differences of means by univariate analysis of variance and post-hoc tests at $\mathrm{p}=0.05$

\section{Fine-root biomass and necromass}

Fine-root biomass significantly differed between collection times (Figure 4a). The highest biomass occurred in September 2018 (181.4 $\left.\mathrm{g} \mathrm{m}^{-2}\right)$, followed by December $2018\left(93.8 \mathrm{~g} \mathrm{~m}^{-2}\right)$, December 2017 (88.4 $\mathrm{g} \mathrm{m}^{-2}$ ), March 2018 $\left(66.4 \mathrm{~g} \mathrm{~m}^{-2}\right)$, and June $2018\left(58.8 \mathrm{~g} \mathrm{~m}^{-2}\right)$. Fine-root necromass also significantly differed between collection times but showed a different pattern from the biomass (Figure $4 \mathrm{~b}$ ). The highest necromass occurred in December 2018 $\left(260.8 \mathrm{~g} \mathrm{~m}^{-2}\right)$, followed by September 2018 $\left(160 \mathrm{~g} \mathrm{~m}^{-2}\right)$, June $2018\left(120.2 \mathrm{~g} \mathrm{~m}^{-2}\right)$, March 2018 $\left(101.1 \mathrm{~g} \mathrm{~m}^{-2}\right)$, and December $2017\left(67.5 \mathrm{~g} \mathrm{~m}^{-2}\right)$.

Fine-root production, mortality and decomposition

Fine-root production, mortality and decomposition varied between time intervals
(Figure 5), generally being higher during JuneSeptember and September-December than during December-March and March-June. The highest decomposition occurred from SeptemberDecember $\left(2.55 \mathrm{~g} \mathrm{~m}^{-2} \mathrm{day}^{-1}\right)$, followed by JuneSeptember (2.54 $\mathrm{g} \mathrm{m}^{-2}$ day $\left.^{-1}\right)$, March-June (1.59 $\mathrm{g} \mathrm{m}^{-2}$ day $^{-1}$ ), and December-March $1.05 \mathrm{~g} \mathrm{~m}^{-2}$ $\left(\mathrm{day}^{-1}\right.$ ) (Figure 5a). The pattern of fine-root mortality differed from that of decomposition, with the highest mortality occurring during June-September $\left(3.06 \mathrm{~g} \mathrm{~m}^{-2}\right.$ day $\left.^{-1}\right)$, followed by September-December $\left(2.69 \mathrm{~g} \mathrm{~m}^{-2}\right.$ day $\left.^{-1}\right)$, MarchJune $\left(2.07 \mathrm{~g} \mathrm{~m}^{-2}\right.$ day $\left.^{-1}\right)$, and December-March $\left(1.37 \mathrm{~g} \mathrm{~m}^{-2}\right.$ day $\left.^{-1}\right)$ (Figure $5 \mathrm{~b}$ ).

The trend for production was similar to that for mortality, with the highest production occurring from June-September $\left(3.62 \mathrm{~g} \mathrm{~m}^{-2}\right.$ $\left.\mathrm{day}^{-1}\right)$, followed by September-December (3.48 $\mathrm{g} \mathrm{m}^{-2}$ day $\left.^{-1}\right)$, March-June $\left(2.0 \mathrm{~g} \mathrm{~m}^{-2}\right.$ day $\left.^{-1}\right)$, and December-March (1.44 $\mathrm{g} \mathrm{m}^{-2}$ day $\left.^{-1}\right)$ (Figure 5c). Total amounts of fine-root production, mortality 

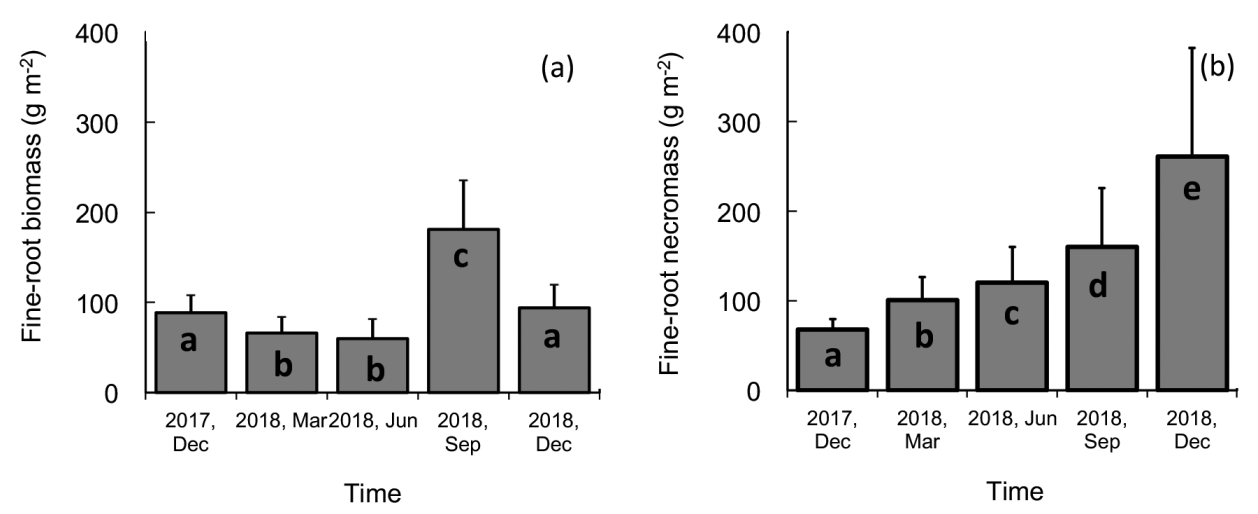

Figure 4 Fine-root biomass (a) and necromass (b) in different collected times; bars indicate \pm standard errors, different letters indicate significant differences of means by univariate analysis of variance and post-hoc tests at $\mathrm{p}=0.05$

and decomposition over one year in the Acacia plantation were $9.90,8.39$ and 7.07 tonnes ha ${ }^{-1}$ respectively (Figure 6) respectively.

\section{DISCUSSION}

The bootstrap 95\% confidence intervals of the estimates that were made in the present study were large (Figures 5 and 6), mostly due to the propagation of measurement errors in the calculations, each of which involved several variables $\left(\mathrm{B}_{\mathrm{i}}, \mathrm{B}_{\mathrm{j}}, \mathrm{N}_{\mathrm{i}}, \mathrm{N}_{\mathrm{j}}\right.$, and $\left.\gamma_{\mathrm{ij}}\right)$ that contained variations. The propagation of measurement errors is a problem that cannot be avoided when several measurements are used to derive an estimate by bootstrapping. The particularly high 95\% confidence intervals for production, mortality and decomposition from JuneSeptember (Figure 5) resulted from high standard errors of the decomposition ratio (Figure 3), biomass (Figure 4a), and necromass (Figure 4b) during this period. Larger sample sizes may reduce these standard errors and thus improve the accuracy of the estimates substantially, with the necessary sample sizes depending on the vegetation types and site conditions (Osawa \& Aizawa 2012).

Examination of the vertical fine-root profile in a range of forest types has shown that most of the fine-roots are distributed in the surface layer of soil (Ademek et al. 2011, Maeght et al. 2015, Tran \& Sato 2018), and a similar distribution was observed in the present study. This can be explained by the fact that fine-roots physiologically capture and transport water and nutrients to support the survival and growth of a tree (Pierret et al. 2016) and the surface layer of soil has the highest fertility and moisture content in the soil profile (Germon et al. 2018). However, in the study of plantation and other forest types (Laclau et al. 2010, Prieto et al. 2015, Christina et al. 2017), the proportion of live fine-roots in deeper soil increased during winter or the dry season, which would increase the likelihood of absorbing water during drought. On the other hand, the proportion of live fine-roots in the $0-20 \mathrm{~cm}$ soil layer in the present study increased in summer or rainy season (Figure $1 b$ ), when the soil moisture content was higher due to high rainfall (Figure 2). The dependence of fine-root production on the soil water content and fertility has previously been reported by Canham et al. (2015), who found higher levels of fine-root production in soil with higher moisture content and fertility. Similarly, Nguyen et al. (2019) observed higher levels of fine-root production in a plantation during rainy season compared with dry season and in a fertilisation treatment compared with a non-fertilisation treatment and concluded that this was due to the greater ability of larger numbers of fine-roots to absorb nutrients and water efficiently. Thus, fine-root biomass and production are also higher in the 0-20 cm soil layer, which may also be related to the greater oxygen content in shallower layers (Neira et al. 2015).

The decomposition ratio of dead fine-roots is affected by the soil microorganisms, surrounding environment (temperature, moisture), and litter quality (nitrogen content) (Fujimaki et al. 2008, Krishna \& Mohan 2017). In the present study, the lowest decomposition ratio occurred from 

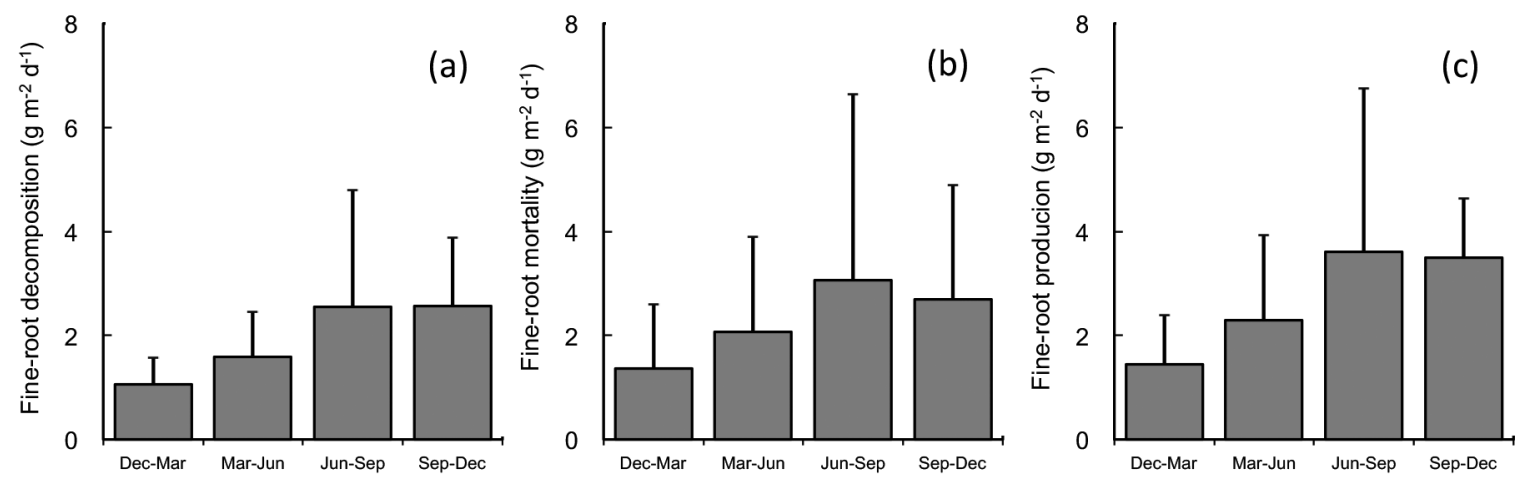

Figure 5 Decomposition (a), mortality (b), and production (c) of fine-roots at three-month intervals; bars indicate the upper $95 \%$ confidence interval limits based on the bootstrap method

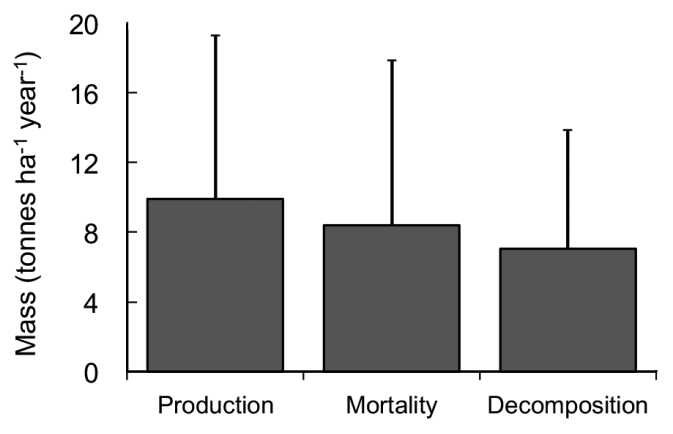

Figure 6 Total fine-root decomposition, mortality and production in a one year duration; bars indicate the upper $95 \%$ confidence interval limits based on the bootstrap method

September-December (Figure 3), which could be explained by the low soil moisture content and temperature (Figure 1a) leading to reduced activities of the soil microorganism (He et al. 2010). By contrast, subsequent increases in the soil moisture content as a result of rainfall and in the surrounding temperature from DecemberMarch (Figure 1) would have promoted soil microorganism activity, leading to the highest decomposition ratio being observed (Figure 3). Further increases in temperature (reaching $39^{\circ} \mathrm{C}$ in July) and precipitation (380 $\mathrm{mm}$ in August) might have led to reduced decomposition ratios during March-June and June-September due to the inhibition of microbial activities (Krishna \& Mohan 2017).

Fine-roots grow, die and decompose simultaneously (Osawa \& Aizawa 2012) and have a short longevity compared with trees (Repo et al. 2014). The significantly higher fine-root biomass that was observed in September 2018 (Figure 4a) could be explained by this being the growing season of trees, when the most nutrients and water are required. Seasonal differences in the fine-root biomass were also observed by Cavelier et al. (1999) in a semi-deciduous lowland forest, whereby the biomass were higher in the wet season compared with the dry season. Therefore, it appeared that the fine-root biomass and necromass could be significantly related to the growing season of specific species and/or forest types (Tran et al. 2015, Tran \& Sato 2018) in different geographical locations.

Fine-root mortality was highest from JuneSeptember (Figure 5), which was the rainy season in the study area. Increased amounts of dead fineroots create more opportunities for the growth of new fine-roots to support the growth of the tree during the growing season (Maeght et al. 2015), which would explain why production was also high at this time (Figure 5). Seasonal variations in fine-root production might also influence the growing season of Acacia hybrid trees, as the highest level of fine-root production occurred in 
the growing season (June-September) and the lowest level, in winter/early spring (DecemberMarch). Fine-root decomposition returned the nutrients, such as nitrogen, phosphorous and potassium, that were accumulated in the biomass to the soil and were highest from June-September (Figure 5). It was estimated that 7.07 tonnes ha ${ }^{-1}$ of fine-roots were decomposed during the study year (Figure 6), indicating the importance of fine-roots in carbon and nutrient cycling in forest ecosystems in general and in Acacia plantations in particular. Other researchers have also indicated the importance of fine-roots in carbon and nutrient fluxes, which are more important than other pools (Graefe et al. 2008, Girardin et al. 2010, Katayama et al. 2019). Since fine-roots absorb nutrients to keep the tree alive (Pierret et al. 2016), forest growers who intend to fertilise plantations should do so when there are more live fine-roots to ensure more efficient absorption of the applied fertiliser.

Fine-root production, mortality and decomposition vary among forest ecosystems worldwide (Table 1) due to different species compositions, forest types, geographical locations, and altitudinal gradients (Usman 2002, Moser et al. 2010). The methods used also affected the estimated fine-root parameters. For example, the decision matrix (Fairley \& Alexander 1985) and rhizotron (Bernier \& Robitaille 2004) techniques do not include fine-root decomposition in the estimation, while the continuous inflow method that was used in the present study does. Therefore, local estimates of fine-root production will improve our understanding of forest carbon cycling and nutrient return in specific forests.

\section{CONCLUSONS}

Information on the vertical distribution, production, mortality and decomposition of fineroots is important for the sustainable management of plantations and for understanding the carbon cycle and soil nutrient cycling. In the Acacia hybrid plantation investigated here, more than $78 \%$ of fine-roots were distributed in the $0-20 \mathrm{~cm}$ soil layer while less than $4 \%$ were distributed in the $50-80 \mathrm{~cm}$ soil layer. A greater proportion of fine-roots was distributed in the $0-20 \mathrm{~cm}$ soil layer during the summer/rainy season compared with the winter/dry season. The total fine-root production, mortality and decomposition in

Table 1 Fine-root production, mortality and decomposition in different forest ecosystems worldwide

\begin{tabular}{|c|c|c|c|c|c|}
\hline \multirow[t]{2}{*}{ Location } & \multirow[t]{2}{*}{ Forest type } & \multicolumn{3}{|c|}{ Mass (tonnes ha-1 year $^{-1}$ ) } & \multirow[t]{2}{*}{ Source } \\
\hline & & Production & Mortality & Decomposition & \\
\hline $\begin{array}{l}\text { North-east } \\
\text { Vietnam }\end{array}$ & Acacia hybrid plantation & 9.90 & 8.39 & 7.07 & Present study \\
\hline $\begin{array}{l}\text { North-east } \\
\text { Vietnam }\end{array}$ & $\begin{array}{l}\text { Acacia mangium } \\
\text { plantation }\end{array}$ & 10.40 & 8.75 & 7.95 & Nguyen et al. 2019 \\
\hline $\begin{array}{l}\text { North-east } \\
\text { Vietnam }\end{array}$ & $\begin{array}{l}\text { Evergreen broadleaved } \\
\text { forest }\end{array}$ & 1.32 & 1.21 & 0.40 & Tran \& Sato 2018 \\
\hline $\begin{array}{l}\text { Central } \\
\text { Japan }\end{array}$ & $\begin{array}{l}\text { Chamaecyparis obtuse } \\
\text { plantation }\end{array}$ & 7.55 & 3.71 & 1.53 & Osawa \& Aizawa 2012 \\
\hline $\begin{array}{l}\text { Thuringia, } \\
\text { Germany }\end{array}$ & $\begin{array}{l}\text { Temperate broad- } \\
\text { leaved forest }\end{array}$ & 1.38 & & able & Meinen et al. 2009 \\
\hline $\begin{array}{l}\text { South-west } \\
\text { Japan }\end{array}$ & $\begin{array}{l}\text { Sub-tropical old-growth } \\
\text { forest }\end{array}$ & 5.66 & 3.83 & 2.41 & Tran et al. 2015 \\
\hline Amazon & $\begin{array}{l}\text { Primary tropical old- } \\
\text { growth rainforest }\end{array}$ & 2.08 & & able & Aragao et al. 2009 \\
\hline $\begin{array}{l}\text { Sarawak, } \\
\text { Malaysia }\end{array}$ & $\begin{array}{l}\text { Bornean tropical } \\
\text { rainforests }\end{array}$ & 4.47 & 1.18 & 1.07 & Katayama et al. 2019 \\
\hline \multirow[t]{2}{*}{$\begin{array}{l}\text { Sabah, } \\
\text { Malaysia }\end{array}$} & $\begin{array}{l}\text { Swietenia macrophylla } \\
\text { plantation }\end{array}$ & 0.58 & \multicolumn{2}{|c|}{ Not available } & Inagaki et al. 2009 \\
\hline & $\begin{array}{l}\text { Araucaria cunninghamii } \\
\text { plantation }\end{array}$ & 2.43 & \multicolumn{2}{|c|}{ Not available } & \\
\hline
\end{tabular}


the Acacia hybrid plantation were 9.90, 8.39 and 7.07 tonnes ha ${ }^{-1}$ year ${ }^{-1}$ respectively. However, these parameters were also found to be seasonally dependent, being higher in the summer than the winter. Therefore, it is recommended that fertilisation should be applied to the $0-20 \mathrm{~cm}$ soil layer from June-September to increase the efficiency of absorption of the applied fertiliser, as the highest level of fine-root production occurs at this time.

\section{ACKNOWLEDGEMENTS}

This research was funded by Vietnam National Foundation for Science and Technology Development (NAFOSTED) under grant number 106-NN.06-2016.10. I would like to thank NT Thang, VT Lam, NH Thinh, and TH Quy for field support.

\section{REFERENCES}

Ademer M, Corre M \& Holscher D. 2011. Responses of fineroots to experimental nitrogen addition in a tropical lower montane rain forest, Panama. Journal of Tropical Ecology 27: 73-81.

Aragao LeOC, Malhi Y, Metcalfe DB et al. 2009. Above- and below-ground net primary productivity across ten Amazonian forests on contrasting soils. Biogeosciences 6: 2759-2778.

Bernier PY \& Robitaille GA. 2004. Plane intersect method for estimating fine-root productivity of trees from minirhizotron images. Plant and Soil 265: 165-173.

Canham CA, Froend RH \& Stock WD. 2015. Rapid root elongation by phreatophyte seedlings does not imply tolerance of water table decline. Trees 29: 815-824.

Cavelier J, Wright SJ \& SantaMarchia J. 1999. Effects of irrigation on litterfall, fine-root biomass and production in a semi deciduous lowland forest in Panama. Plant and Soil 211: 207-213.

Christina M, Nouvellon Y, LaClau JP ET AL. 2017. Importance of deep water uptake in tropical eucalypt forest. Functional Ecology 31: 509-519.

Efron B \& Gong G. 1983. A leisurely look at the bootstrap, the jackknife, and cross-validation. The American Statistician 37: 36-48.

FAIRley RI \& AlexANDER IJ. 1985. Methods of calculating fineroot production in forests. Pp 37-42 in Fitter AH et al. (eds) Ecological Interactions in Soil: Plants, Microbes and Animals. Blackwell Scientific Publications, Oxford.

Freschet GT, Cornwell WK, Wardle DA et al. 2013. Linking litter decomposition of above- and below-ground organs to plant-soil feedbacks worldwide. Journal of Ecology 101: 943-952.

Fujimaki R, Takeda H \& Wiwatiwitaya D. 2008. Fine-root decomposition in tropical dry evergreen and dry deciduous forests in Thailand. Journal of Forest Research 13: 338-346.
Germon A, Guerrini IA, Bordron B et AL. 2018. Consequences of mixing Acacia mangium and Eucalyptus grandis trees on soil exploration by fine-roots down to a depth of $17 \mathrm{~m}$. Plant and Soil 424: 203-220.

GILL R \& JACKSON RB. 2000. Global patterns of root turnover for terrestrial ecosystems. New Phytologist 147: 13-31.

Girardin CAJ, Manhi Y, Aragao EOC et al. 2010. Net primary productivity allocation and cycling of carbon along a tropical forest elevational transect in the Peruvian Andes. Global Change Biology 16: 3176-3192.

GORDON WS \& JACKSON RB. 2000. Nutrient concentrations in fine-roots. Ecology 81: 275-280.

Graefe S, Hertel D \& Leuschner C. 2008. Estimating fineroot turnover in tropical forests along an elevational transect using minirhizotrons. Biotropica 40: 536-542.

He X, Lin Y, Han G, Guo P \& Tian X. 2010. The effect of temperature on decomposition of leaf litter from two tropical forests by a microcosm experiment. European Journal of Soil Biology 46: 200-207.

Inagaki M, Inagaki Y, Kamo K \& Titin J. 2009. Fine-root production in response to nutrient application at three forest plantations in Sabah, Malaysia: higher nitrogen and phosphorus demand by Acacia mangium. Journal of Forest Research 14:3: 178-182.

Katayama A, Kho LK, Makita N, Kume T, Matsumoto K \& OHAshi M. 2019. Estimating fine-root production from ingrowth cores and decomposed roots in a Bornean tropical rainforest. Forests 10: 36.

Keenan RJ, Reams GA, Achard F, de Freitas JV, Grainger A \& LindQuist E. 2015. Dynamics of global forest area: results from the FAO global forest resources assessment 2015. Forest Ecology and Management 352: 9-20.

Kien ND, Thinh HH, Kha LD, NGHia NH, Hai PH \& Hung TV. 2014. Acacia as a national resource of Vietnam. Pp 20 in Compendium of Abstracts Acacia 2014: Sustaining the Future of Acacia Plantation Forestry. International Conference, IUFRO Working Party 2.08.07: Genetics and Silviculture of Acacia. 18-21 March 2014, Hue.

Krishna MP \& Mohan M. 2017. Litter decomposition in forest ecosystems: a review. Energy, Ecology and Environment 2: 236-249.

Laclau JP, Nouvellon Y, Reine C et al. 2010. Mixing eucalyptus and acacia trees leads to fine-root overyielding and vertical segregation between species. Oecologia 172: 903-913.

LAI TH \& Tran VD. 2019. Fineroot dynamics and production in Acacia auriculiformis plantation. Plant Cell Biotechnology and Molecule Biology 20: 604-610.

Luyssaert S, Inglima I, Jung M ET AL. 2007. $\mathrm{CO}_{2}$ balance of boreal, temperate, and tropical forests derived from a global database. Global Change Biology 13: 2509-2537.

Maeght JL, Gonkhamdee S, Clement C, Ayutthaya Sil, Stokes A \& Pierret A. 2015. Seasonal patterns of fine-root production and turnover in a mature rubber tree (Hevea brasiliensis Müll. Arg.) stand-differentiation with soil depth and implications for soil carbon stocks. Frontiers in Plant Science 6: 1022.

MalHI Y. 2012. The productivity, metabolism and carbon cycle of tropical forest vegetation. Journal of Ecology 100: $65-75$.

McCormack ML \& Guo D. 2014. Impacts of environmental factors on fine-root lifespan. Frontiers in Plant Science 5: 205. 
Meinen C, Herte D \& Leuschner C. 2009. Root growth and recovery in temperature broad-leaved forest stands differing in tree species diversity. Ecosystems 12: 1103-116.

Moser G, Leuschner C, Roderstein M, Graefe S, Soethe N \& Hertel D. 2010. Biomass and productivity of fine and coarse roots in five tropical mountain forests stands along an altitudinal transect in southern Ecuador. Plant Ecology E Diversity 3: 151-164.

Neira J, Ortiz M, Morales L \& Acevedo E. 2015. Oxygen diffusion in soils: understanding the factors and processes needed for modeling. Chilean Journal Agriculture Research 75: 35-44.

Nguyen TT, Vu TL, Nguyen HS et al. 2019. Changes in fineroot growth dynamics in response to phosphorus application in an Acacia mangium plantation in Vietnam. New Forests in press. doi: 10.1007/s11056019-09763-4.

Osawa A \& Aizawa R. 2012. A new approach to estimate fineroot production, mortality, and decomposition using litter bag experiments and soil core techniques. Plant and Soil 355: 167-181.

Pierret A, Maeght JL, Clement C, Montoroi JP, Hartmann C \& GonkHAmdeE S. 2016. Understanding deep roots and their functions in ecosystems: an advocacy for more unconventional research. Annals of Botany 118: 621-635.

Prieto I, Roumet C, Cardinael R et al. 2015. Root functional parameters along a land-use gradient: evidence of a community-level economics spectrum. Journal of Ecology 103: 361-373.

QCVN02. 2009. Vietnam Building Code. Natural Physical $\mathcal{E}$ Climatic Data for Construction. Ministry of Construction. Hanoi.
Repo T, Sirkia S, Heinonen J et al. 2014. Effects of frozen soil on growth and longevity of fine-roots of Norway spruce. Forest Ecology and Management 313: 112-122.

Saifuddin M \& Normaniza O. 2016. Rooting characteristics of some tropical plants for slope protection. Journal of Tropical Forest Science 28: 469-478.

TRAN VD \& SATo T. 2018. Towards carbon certificate in Vietnam: Net ecosystem production and basic income for local community. Pp 79-96 in Marchio L \& Jafar S (eds) Environmental Resources Use and Challenges in Contemporary Southeast Asia: Tropical Ecosystems in Transition. Springer, Singapore.

Tran VD, Sato T, Saito S \& Kozan O. 2015. Fine-root production and litterfall: main contributions to net primary production in an old-growth evergreen broad-leaved forest in southwestern Japan. Ecological Research 30: 921-930.

Usman S. 2002. Production and decomposition of fine roots in central Himalayan forest species. Journal of Tropical Forest Science 14: 26-34.

Valverde-Barrantes O J, Raich JW \& Russell AE. 2007. Fine-root mass, growth and nitrogen content for six tropical tree species. Plant and Soil 290: 357-370.

YAN XL, JiA L \& DAI T. 2019. Fine-root morphology and growth in response to nitrogen addition through drip fertilization in a Populus $\times$ euramericana "Guariento" plantation over multiple years. Annals of Forest Science 76: 13. 